Martin D. Henry (ITQ, vol. 67/4, 2002, )

\title{
The Weakness and Strength of Christianity
}

That divine and human wisdom do not necessarily coincide, is an ancient idea, whose validity, in the Christian world at any rate, may not depend solely on the rhetorical talent of its first proponent, St Paul. Similarly, the reversal of apparently self-evident ideas - for example, that strength is superior to weakness, or that fame is preferable to obscurity - has not just been part of the stock-in-trade of Christian apologetics over the centuries, but seems to be woven into the fundamental experience of humanity. 'Greatness' comes eventually to be revealed as megalomania, and 'fame', as the Chinese sage, Chuang Tzu, has it, 'is the beginning of disgrace’.

In Christianity, the symbol of crucifixion is held to embody the paradox of 'strength in weakness' in so unsurpassable a form that it is, perhaps for that very reason, also taken to reveal the most incontrovertible and inescapable truth about the human condition, characterised as it is by contingency or uncontrollability. Human passivity in the endurance of suffering and death - life's two constants - is concentrated unforgettably in the image of a public crucifixion, but so also is the refusal to shirk the misfortunes of reality, without which life is unimaginable. It is as if existence without pain were a contradiction in terms, and as if faith in the value of existence were not open to negotiation, because nothing could ever be strong enough or awful enough to undermine it: so the universal language of the cross.

So far, so good. Yet the fact that something cannot be undermined, does not necessarily make it true. That must be granted. But, on the other hand, to want to know what the 'positive' truth of Christian faith consists in, to want to know why, for example, there is good and evil in the world, or to want to know what, for example, 'resurrection' means, would be like 
wanting to have absolute control of life, or in more traditional language, it would be like wanting to 'be like God', or again, to use the images already evoked, it would be like wanting to transcend the limits of evil and suffering and death that the cross simplifies, intensifies, and clarifies for us. It cannot be done. And any claim that it had been done, must be fraudulent. Not that humanity's appetite for such hidden knowledge ever wanes, but attempts to satisfy it are always lethal. Hence it is probably good that the positive truth of Christianity can only be seen with the eyes of faith, but can never be known. The weakness of Christianity - that no one knows what it means - is therefore, once again, its strength, and so the snide remark, attributed, if I recall correctly, to Lenin, that 'theology is a subject without an object' is not - at least as far as Christianity is concerned - a jibe to be anxiously refuted, but an unwitting revelation of Christian truth. 